\title{
Strategies for Improving the Quality of Public Services at the Ministry of Agrarian Affairs and the National Land Agency of North Luwu Regency
}

\author{
Syahiruddin Syah ${ }^{1}$, Amir Imbaruddin ${ }^{1}$, Manan Sailan ${ }^{1}$, Hamsu Abdul Gani ${ }^{1}$ \\ ${ }^{1}$ Public Administration, Postgraduate Program, Makassar State University, Indonesia \\ Received: September 19, 2020 \\ Revised: September 27, 2020 \\ Accepted: September 29, 2020
}

\begin{abstract}
This study aims to analyze and examine strategies for improving the quality of public services at the Ministry of Agrarian Affairs and the National Land Agency of North Luwu Regency. The method is qualitative research with data collection techniques in this study include interviews and observations. The data analysis process used an interactive model analysis with data analysis including data reduction, data presentation, and conclusion drawing. The results show obstacles in implementing strategies for improving the quality of land services, including the capacity and capability of the apparatus personnel who are not yet fully capable of carrying out service functions based on predetermined SOPs, including the lack of human resources who have expertise in land affairs. Apart from that, the support for facilities and infrastructure which greatly supports the implementation of land service functions in the field is still very limited. The cultural strategy that needs to be put forward is how to build a work culture that is flexible and sensitive to the needs of land service users. This is considered important, given the complexity of problems surrounding land administration management, which is still a major problem and is in the public spotlight. The facts that the researchers found in the field prove that land problems, especially those related to the work culture of land service officials, are still a matter of concern for people who use land services.
\end{abstract}

Keywords: Service Strategy, Service Quality, Culture

\section{Introduction}

In general, the level of public services in Indonesia is still low. Meanwhile, public service is not something new. There are several things that indicate the existence of important problems in the delivery of public services, first, increasing indications of service discrimination in provision. This happens because of the strong factors of political affiliation, ethnic and religious networks so that it is greatly influenced by the balance of service relations. Second, there is no certainty about the cost and time of service. This uncertainty is often the cause of the emergence of KKN (Colluction, Corruption, Nepotism) because service users tend to choose to pay high bribes to service providers to obtain certainty and quality of service. Third, the low level of community satisfaction with public services. This is a logical consequence of service discrimination and uncertainty (Rudiyanto, 2012).

The bureaucracy is basically a servant, not a master. The problem is, these perceptions are not instilled in the bureaucratic environment. As a result, bureaucratic arrogance emerges, such as feeling the most needed by many people, or acting casually to society. The attitude shown by most of the bureaucratic apparatus makes the community feel that they are not getting the service as expected, even the people often feel neglected by the bureaucratic apparatus (Rusli, 2013).

The poor public services that have occurred so far are due to the absence of a clear paradigm in the delivery of public services. The service performance provided by the existing bureaucracy is still quite strong in the character of serving power (state-oriented) compared to 
the public (public-oriented) so that the face of the Indonesian bureaucracy is quite authoritarian. Facts related to the condition of public services in Indonesia are the themes raised in several studies, including research conducted by the World Bank and UGM on the performance of public services using a number of variables, namely equity, responsiveness, service efficiency, bribery, and bureaucratic rent. (Dwiyanto, 2003). The results of the 2002 Good Governance Survey conducted by UGM can be used to describe the condition of public services in Indonesia which are still full of bureaucratic interests.

Referring to the concept of New Public Services, the fundamental factor that needs to be considered in service provision is that public services performed by the government are not to serve customers, but services provided to serve the community or the term citizen (Denhardt \& Denhardt, 2003; Perry, 2007; Windrum, 2008). In a good strategy there is work team coordination, has a theme, identifies supporting factors that are in accordance with the principles of implementing ideas rationally, is efficient in funding, and has tactics to achieve goals effectively (Hyndman \& Eden, 2000). The strategy is distinguished from tactics that have a narrower scope and shorter time, although in general people often confuse the two words. Besides, the strategy that should not be overlooked is the synergy between agencies so that efforts to improve service quality are efficient and effective

Strategic support is an absolute requirement in implementing standards and community participation in the delivery of public services. Therefore this study aims to analyze and examine strategies for improving the quality of public services at the Ministry of Agrarian Affairs and the National Land Agency of North Luwu Regency.

\section{Methods}

This research is a qualitative research that aims to obtain a realistic-holistic picture and more in-depth information about public services in the land sector at the Ministry of Agrarian Affairs and the National Land Agency of North Luwu Regency. Data collection techniques in this study include interviews and observations. The public service strategy used refers to David Osborne's theory, namely the core strategy, consequence strategy, customer strategy, control strategy, and culture strategy. To obtain data on strategies for improving the quality of public services in the land sector, the key informant is the Head of BPN (National Land Agency), service users or residents who come to take care of land administration at the BPN Office of North Luwu Regency. The data collection techniques used were in-depth interviews and observations. The data analysis process used an interactive analysis model (Huberman et al., 2014). The components in data analysis include data reduction, data presentation, and drawing conclusions.

\section{Results and Discussion}

In order to improve the image of good and professional public services in the land sector, the Ministry of Agrarian Affairs and the National Land Agency of North Luwu Regency, as a liaison between the government and the community in providing land services, have made various efforts to improve the quality of land services in North Luwu Regency. The strategy for improving the quality of land services is an absolute requirement for the regional government of the North Luwu Regency to minimize various problems in the land sector, especially in improving the performance and performance of land apparatus, both in terms of service delivery, systems, and resources owned.

The analysis of the success of the strategy for improving the quality of public services in the land sector will be explored using an analysis knife based on the theory of Osborne \& Plastrik (1997) which uses 5 strategic indicators, namely Core strategy, consequence strategy, customer strategy, control strategy, and culture strategy. These five strategies are indicators used in 
measuring the success of public service strategies in the land sector in the North Luwu Regency.

In the context of the public service strategy at the Ministry of Agrarian Affairs and the National Land Agency of North Luwu Regency, from the aspect of the role and capacity of leadership, there are still many obstacles that greatly affect the implementation of the service process. Based on the findings in the field, various facts related to commitment and quality of leadership were found, including the quality and qualifications of public service personnel in the land sector. Leadership performance is a major highlight which is considered to be one of the sources of land service problems in the North Luwu Regency.

From the informants' presentation regarding the organizational capacity in the land service pattern in North Luwu Regency, it is clear that the land service is in a chronic condition that needs to be addressed immediately. Issues that have surfaced and become obstacles that have attracted considerable attention are the weak coordination between fields, the lack of staff with skills in the land sector, and insufficient facilities and infrastructure to support the implementation of land service duties and functions.

The strategy in implementing land services at the North Luwu Regency Land Agency is a systemically formulated method that includes determining policies, programs, actions, decisions, or resource allocation by taking into account environmental influences in efforts to achieve organizational goals. The strategy for improving the quality of land services in North Luwu Regency will be explored using an analysis knife based on the theory of Osborne \& Plastrik (2001), namely:

\section{Core Strategy}

The core strategy aims to clarify the mission and vision of the organization. This strategy can be operationalized through approaches in the form of clarifying organizational goals by making preparations before operating the organization, clarifying the roles of company leaders and employees, and clarifying the direction of the organization by improving organizational goals. Reorganization based on duties and functions is absolutely necessary in order to further clarify the objectives of a government organization. Regional heads in preparing SKPDs (Regional Work Units) and Work Units in their regions should separate fundamentally different functions into different organizations. By reorganizing based on this function, each organization will concentrate on achieving a clear goal.

In connection with clarifying the organization's vision and mission, the most important thing to do by the North Luwu Regency BPN is to provide an understanding to all parties about the importance of carrying out land registration. This step is then followed by the preparation of a strategic plan in the form of a work program to achieve land service objectives.

The Land Office of Luwu Utara Regency as a government agency does not only carry out a mission, one of which is to improve the order of life together that is more just and dignified in relation to control, ownership, use, and utilization of land (P4T). In other words, the North Luwu Regency Land Office strives to provide the best service in control, ownership, use, and utilization of land for the community. Therefore, the capacity, capability, and reliability of the North Luwu Regency Land Office staff in providing services to the applicant/community is very important.

The implementation of the core strategy in order to improve the quality of land services at the Office of the Ministry of Agrarian Affairs and BPN in North Luwu Regency can be seen from the support of the leader or in this case the Head of the Office to realize the provision of quality services, including the placement of employees according to expertise. 
Furthermore, the Head of the Land Agency also stated that the internal strategy implemented within the scope of the national land agency office is generally adjusted to the demands of the community. This means that aspirations and complaints that come from the community are accommodated and then used as material for consideration in formulating a strategy for developing land services in North Luwu Regency.

Viewed from the aspect of the organizational dimension, reforms are carried out by increasing the capacity of personnel within the BPN. Through the new organization, employees are motivated to change slowly but surely so that their performance is better. Various kinds of training and personnel training are held, including periodic employee rotation. Related to this, the Office of the Ministry of Agrarian Affairs and the BPN of North Luwu Regency, in this case, the leadership, looks more intensive in providing appeals and admonitions to all employees to be more professional in carrying out land service functions. In addition, attention is paid to employee performance, in particular giving awards to employees who are disciplined and excel in carrying out their duties. This is important, in order to motivate other employees to carry out their duties professionally.

Along with the process of reforming land services, at the same time complaints from the community regarding the processes and procedures for land services continue to roll. Dissatisfaction with the service performance of the civil servants has almost resulted in an attitude of apathy and even distrust of the performance of the apparatus in the land administration service process. The complexity of the problem in the scope of the North Luwu Regency National Land Agency has been highlighted by various parties, both from the community members who use land services, as well as from the DPRD (Regional People's Representative Assembly) who also accommodate the aspirations of the community regarding public services in the land sector.

The results of interviews with DPRD members have further strengthened the indication that the practice of land services at the BPN office in the North Luwu Regency is still not optimal. BPN's internal problems have not been resolved, so it is not surprising that many complaints have come from users of land services. The problems surrounding land services are of course inseparable from the role and commitment of the BPN leadership or head in anticipating various existing problems. Various complaints from residents related to the service process that seems sluggish and the behavior of some elements of the apparatus who often take actions outside the rules or procedures that apply, actually become an evaluation material to continue to make improvements to the performance of land services.

Based on the results of researchers' observations of the land administration management process, and interviews of researchers with several key informants, related to the core strategy or core strategy, it can be said that the core strategy is implemented, especially from the aspects of leadership and employee development in the office of the Ministry of Agrarian Affairs and the Land Agency. In general, North Luwu Regency is running well but has not had a significant impact on improving the quality of land services. Even though the internal party at the BPN office stated that they had tried their best and had taken various steps in order to improve the quality of land services, at the same time, complaints from the community who used land services were increasing. In fact, most people feel dissatisfied with the performance of land services at the Ministry of Agrarian Affairs and BPN Office of North Luwu Regency.

\section{Consequences Strategy}

The consequence strategy aims to create conditions for healthy competition among other public service providers. In addition, this strategy also encourages organizations to provide employees 
with high incentives and disincentives to follow and comply with the rules made by an organization.

In general, the Ministry of Agrarian Affairs and the North Luwu Regency National Land Agency have made efforts to meet the service standards set by the government. One of them is consistency in implementing reward and punishment. This is very important in increasing employee motivation and work ethic so that they can work more professionally.

In public service, community satisfaction can be achieved if the human resources who are directly involved in the service can understand and appreciate and desire to provide quality service. In order for service human resources to truly support the improvement of the quality of public services, it is necessary to properly manage HR services including the identification of HR needs needed in order to provide services in accordance with predetermined service standards, especially with regard to competence and qualifications for the role will be played in every service process. In addition, it is also necessary to identify the needs for human resource development and planning, the development of service ethics needed so that employees remain within the boundaries that have been determined in providing services. To improve the competence of human resources for service personnel, consistent planning is required for the development and improvement of the competence of service human resources, both through technical and functional training and training.

This consequent strategy can be realized through strengthening the quality of human resources, which is implemented in the form of implementing technical guidance and training to improve skills or skills in the land sector. The Office of the Ministry of Agrarian Affairs and the BPN of North Luwu Regency have facilitated several personnel or employees to participate in several types of training activities that are carried out centrally.

The complex issues surrounding land services in North Luwu Regency are generally almost the same as other areas in Indonesia. According to the head of the North Luwu Regency BPN, there are several main problems in terms of land services, first, the lack of professional staff or human resources who have expertise in the land sector within the office of the Ministry of Agrarian Affairs and BPN in North Luwu Regency. Second, mental problems or behavior of BPN office employees who are not very supportive of the land service process. Third, the employee discipline factor, there are still many employees who enter the office after 9 o'clock, especially land surveying officers. The reason for the delay that was often cited by the officer was because he had to draw the location of the land measurement at his house. This was done because the facilities and equipment used in the office were very limited.

In connection with the statement of the Head of the Office of the Ministry of Agrarian Affairs and BPN of North Luwu Regency, it is clear that problems concerning facilities and infrastructure, which are one of the most supportive factors in improving the quality of land services, are still a problem in itself. Especially in the management of land document archives, there are still obstacles in the implementation of land services. Delays in recovering required archival documents are things that often occur. Officers in each section or unit in the office will contact the general department to obtain the necessary documents. This is because the archives in each unit of the office are also in the general section of the office (Main Office Archives).

The existing archive management at the National Land Agency office in the North Luwu Regency has not implemented a technology-supported filing system. This resulted in an ineffective filing system, and the impact was felt directly by the community who used land services. Problems in finding land document data, which if needed, will only contact the general department, to recover the documents needed. In addition, the space used for storing paper documents is only modest and access to the room is restricted. 
The professionalism of employees in the governance of the land service system is a matter that is often questioned by citizens who use land services. The statement by the community using land services regarding the time of completion and the management process that seems to be delayed is reinforced by the fact that the apparatus' ability to carry out document filing duties is very weak. This is evidenced by complaints about missing or scattered land documents or documents caused by the negligence of BPN employees in keeping citizen documents. This fact was also proven by the researcher himself while conducting an interview with one of the BPN employees, where it was seen that there were residents who came to question the status of land certificate management, but when the land documents of the landowner were searched, the employee stated where the documents had been forgotten, and In the end, they had to involve several employees to find the scattered citizen documents. This shows the weakness of the internal filing system in the Ministry of Agrarian Affairs and BPN offices in the North Luwu Regency.

The filing system is an administrative structuring process in organizational administration, which includes recording, storing, maintaining, ensuring the authenticity of these documents, and making archives an important thing in organizational sustainability. To create an effective and efficient administration arrangement, it is better if every organization needs to establish a good filing system for the realization of organizational goals as a whole.

From the results of interviews and direct observations of researchers, it can be concluded that the implementation of consequential strategies in an effort to improve the quality of land services in the North Luwu Regency, has not fully run optimally. Although programs for developing the quality of human resources within the scope of the Ministry of Agrarian Affairs and BPN offices in North Luwu Regency have been implemented, including optimizing facilities and infrastructure as the main support in implementing land services, they have not been fully able to meet the satisfaction and service standards as expected.

\section{Customer Strategy}

The customer strategy aims to create a service delivery system that is carried out by bureaucrats, so as to be able to provide optimal service levels for the community

In connection with the land service administration system, in particular, to ensure legal certainty over lands owned by the people, the government holds land registration throughout the territory of the Republic of Indonesia according to the provisions stipulated by Government Regulation, which is known as Complete Systematic Land Registration or PTSL (Complete Systematic Land Registration). PTSL is the process of registering land for the first time, which is carried out simultaneously for all objects of Land Registration throughout the territory of the Republic of Indonesia in one village or sub-district or other similar names. Through this program, the government guarantees legal certainty or rights to land owned by the community. The PTSL method is an innovation by the government through the Ministry of ATR (Ministry of Agrarian Affairs and Spatial Planning )/BPN to meet the basic needs of the community: clothing, food, and shelter. This program is outlined in the Regulation of the Minister of Agrarian Affairs and Spatial Planning/Head of the National Land Agency No.6 of 2018 concerning Acceleration of Complete Systematic Land Registration and Presidential Instruction No.2 of 2018 concerning Acceleration of Complete Systematic Land Registration throughout the Territory of the Republic of Indonesia. PTSL, which is popularly known as land certificate, is a form of implementation of the Government's obligation to ensure legal certainty and protection of community land ownership. In addition, later on, people who have received land certificates can make the certificates as financial inclusion or business assistance capital that is empowered and successful, in order to improve their welfare. 
The North Luwu National Land Agency (BPN) has implemented the PTSL program and socialized it to all communities in North Mamuju Regency.

In carrying out the function of public services in the land sector, the Ministry of Agrarian Affairs and BPN Office of North Luwu Regency, continue to do their best, in order to optimize the land service system for the community in North Luwu Regency. As explained by several informants regarding land service issues, particularly those related to the quality of human resources, in which the aspect of the capability of human resources inland is still very limited. For example, when service users complain about problems related to land management, BPN office employees are barely able to provide solutions. In fact, the fact that happened to the Office of the Ministry of Agrarian Affairs and BPN in North Luwu Regency, if the community encountered a problem, they could only report the problem to the counter or security guard office, and it was certain that there was no follow-up. Even though there is a complaint counter available, it cannot function properly.

The most important thing in implementing this strategy is the fulfillment of facilities and infrastructure to support land service functions. One of them is the availability of measuring instruments.

In general, in agrarian reform, activities to improve the quality of land services include the planned recruitment of surveyors with the target of achieving a national proportion of surveyors reaching 30\% of all employees of the Ministry of Agrarian and Spatial Planning / BPN. In addition, other activities are increasing the use of geo Computerization of Land Activities (KKP) with the target of utilizing information and computerized technology (ICT) inland services and management in 33 regional offices of the Ministry of Agrarian Affairs and Spatial Planning / BPN and Regency / City land offices.

One solution to measurement problems due to the lack of adequate equipment is to set aside a portion of the tactical funds that go in to independently buy measurement equipment such as the Global Positioning System (GPS) and theodolite. Besides that, also by maintaining and maintaining the existing equipment as well as possible. Meanwhile, for TM-3 maps that have been digitized from manual maps but still many are not suitable for the current situation, the solution to the problem that can be taken is by matching the existing photo map or by checking the field.

The most important thing in strengthening this customer strategy is that it is necessary to implement a program to improve the quality of human resources through education and training as well as to increase the quality and quantity of technical equipment owned to improve services in the land sector to the community. In addition, it is also necessary to hold outreach activities more frequently to the community regarding the procedures and importance of land certification. With this cooperation between the two parties, it is hoped that the vision and mission of the National Land Agency which seeks to become an institution capable of realizing land and land for the greatest welfare of the people, as well as justice and sustainability of the social, national and state systems of the Republic of Indonesia can be realized.

\section{Control Strategy}

The supervisory strategy carried out by the Office of the Ministry of Agrarian Affairs and BPN in North Luwu Regency also aims to empower employees so that the goal of providing satisfying services can be achieved. In addition, the supervisory strategy also functions as a program to maintain the quality of land services provided, so that public trust in the organization can be maintained. One of the efforts of the Office of the Ministry of Agrarian 
Affairs and BPN of North Luwu Regency in optimizing supervision of the implementation of land services is to maintain public trust by monitoring the performance of land services effectively, measuring and evaluating Public Service Operational Standards at the Ministry of Agrarian Affairs and BPN Office of North Luwu Regency. To maintain the quality of service, monitoring and evaluation are carried out in all areas or sections that handle land services, including monitoring the availability of facilities and infrastructure that support the implementation of land service tasks.

The control strategy also demands innovation or new breakthrough ideas in terms of public services that emerge from the apparatus. Innovation can come in various forms, including the formation of new knowledge, methods, objects, technology, or discoveries (Noor, 2013). A product, either in the form of goods or services, can be said to be an innovative product if it is seen as new in the eyes of the market or society, however, the product can be said to be new only in certain areas because the product has previously existed in certain areas. With service innovation, it can simplify and accelerate the services that will be obtained by the community, so that the image of public institutions by the community can be said to be good, and there are no more complaints submitted by the community about bad services. In relation to service innovation, based on the observations of researchers, it appears that the Office of the Ministry of Agrarian Affairs and BPN of North Luwu Regency is still not maximal in implementing innovative policies inland services. Innovative programs in the land sector still follow the Larasita and Prona national programs. This proves that the Office of the Ministry of Agrarian Affairs and BPN in the North Luwu Regency still refers to the national strategy program in the land sector, namely Larasita. The North Luwu Regency BPN should be able to formulate a service innovation model that refers to demands for changes in service patterns that have been implemented. Important lessons from innovative service models that are widely practiced in several provinces in Indonesia, for example, an innovative program to improve the quality of services of the Gresik Regency Land Office by establishing Integrated Land Service Houses, and several other innovative programs in several areas that are adapted to the culture of the people in the area. According to researchers' observations, there is a tendency for leaders to provide less motivation for officials to build and create collaborative innovations. Leaders are more focused on enforcing discipline, improving performance, but are forgotten to explore innovative ideas from their own internal organizations.

The supervisory strategy also functions as a program to maintain the quality of land services provided, so that public trust in the organization can be maintained. One of the factors that can support public trust is a positive response from the land apparatus when the community files complaints regarding land management services. The most important facility is a complaint post that can accommodate complaints and suggestions from the public. The complaint post is an information medium for land service officials, and as an evaluation material for future service performance improvements. Unfortunately, the facts that the researchers found in the field show that the complaint posts in the Ministry of Agrarian Affairs and BPN offices in North Luwu Regency have not been effective. Almost all people who are taking care of land administration feel dissatisfied with the land service process.

The complaint process starts with the community who raises problems to the government, which can be in the form of suggestions, questions, or complaints. The facilities and infrastructure in the form of complaint counters at the Ministry of Agrarian Affairs and BPN in the North Luwu Regency are still not optimal in accommodating various land service problems faced by service users. The existence of a complaint counter at the Ministry of Agrarian Affairs and BPN offices in North Luwu Regency has not been functioning optimally, it can even be said that it is not running at all. 
In fact, the ranks of the Ministry of Agrarian Affairs and BPN of North Luwu Regency need to further optimize this supervision strategy by strengthening internal coordination and involving external elements in overseeing the implementation of land services in North Luwu Regency.

\section{Culture Strategy}

The cultural strategy aims to change the culture that can hinder the direction of change. In the cultural strategy, changes in the mindset and behavior patterns of officials in carrying out their duties and functions as public servants are important, and greatly affect the quality of public services. Organizational culture will greatly affect work culture in an organization, including work culture in the public service sector. In fact, the work culture of "serving" is the main principle that must be put forward by the apparatus in carrying out public service functions. Organizational culture is manifested in the behavior patterns and work ethic of the officials.

In the context of land services, which with the naked eye there are still many problems, demands a change or transformation of work culture, which is adjusted to the demands of the service user community. The cultural strategy that needs to be put forward is how to build a work culture that is flexible and sensitive to the needs of land service users. This is considered important, given the complexity of problems surrounding land administration management, which is still a major problem and is in the public spotlight. The facts that the researchers found in the field prove that land problems, especially those related to the work culture of land service officials, are still a matter of concern for people who use land services.

In connection with this fact, the office of the Ministry of Agrarian Affairs and BPN in the North Luwu Regency are expected to be more responsive and responsive to various existing problems. The role of the leader, in this case, the Head of the Office of the Ministry of Agrarian Affairs and BPN of North Luwu Regency, greatly determines the behavior patterns of the officials in carrying out their duties and functions as land service officials.

The demand for reform of the land service system is an absolute requirement in order to improve the quality of land services. In this case, the transformation of organizational culture for the better is an important prerequisite so that service output can be achieved more optimally. One of the points in the cultural strategy is the ability to innovate, make new breakthroughs in carrying out the role and function of the public service apparatus.

According to the narrative of the Head of the North Luwu Regency BPN, the Larasita program that has been running so far has indeed helped provide a lot of convenience to people who want to take care of land administration. This program is recognized by the community as a program that is quite effective and efficient because officers directly go to the community who want to take care of land documents. From various answers from the community regarding this larasita, it is evident that this innovative program has had a good enough impact on the people who take care of land documents. Most of the people who happened to take care of land documents through larasita stated that they were greatly helped by the service system provided in the process of processing their land documents. However, there are still technical problems associated with the internet network. The rest of the land service system through the Larasita program is proven to be able to assist the implementation of land service functions in general at the Ministry of Agrarian Affairs and BPN offices in the North Luwu Regency. The most important thing in the implementation of land services is how to maximize the capabilities of human resources who have skills in the land sector and develop work attitudes in building good communication with land service users.

Cultural strategy (culture strategy) by establishing provisions regarding a code of ethics that govern the behavior of employees. The Code of Ethics for employees in the North Luwu 
Regency National Land Agency is a guideline for attitudes, moral principles, behavior and actions in government administration, services to the community, and associations with fellow Civil Servants and work partners. This code of ethics is stipulated so that in carrying out their duties as employees at the Office of the Ministry of Agrarian Affairs and BPN, North Luwu Regency, they do not take actions that are contrary to moral responsibility.

Although work behavior guidelines and demands for work morality and professionalism have been echoed both orally and in writing, this does not mean that they can effectively imply a decrease in the practice of dishonorable and irresponsible practices carried out by some elements of the land apparatus. In fact, there are still many cases of extortion reported by the public in the process of land administration management.

Values, norms, and management styles are components of organizational culture. Values are expressed as beliefs about what is good for the organization and desired behavior. Norms are unwritten rules that define expectations of behavior, such as how managers treat subordinates and how subordinates relate to managers. Norms govern how performance management works, whereas management style describes how managers behave and exercise their strength and power. In principle, the organizational culture component is one of the most important parts in realizing the goals, vision, and mission of an organization (Alvesson \& Sveningsson, 2015; Negara, 2020).

In the context of public services, great hope lies in the government's commitment to be able to show public services optimally and at the same time ward off negative images about the government so far. The better the quality of public services, the growing and stronger public trust in the government, and vice versa, the worse the quality of service received by the community, the more people's trust in the government will be lost. This causal relationship begins to appear when employees carry out their work which is shown as attitudes and behaviors at work which are the employee's work culture. Likewise, with the behavior of officials inland services, in fact by referring to the applicable provisions concerning apparatus ethics, it is hoped that deviant and irresponsible practices, such as collusion, corruption, and the like do not need to occur. In essence, the public service process must be free from various disgraceful acts. One example of cases, especially in the process of land management is the rampant cases of extortion or illegal levies which always color the process of land document processing. The existence of cases of extortion is caused by, among other things, the long procedure and time in processing certificates, as this is not desired by the community. In addition, it can create opportunity costs for service users to interact with service providers. As expressed by the opinion of Dwiyanto (2008) that there are frequent practices of extortion (extortion) in almost all public service bureaucracies. This kind of practice is considered mutually beneficial for both users and service providers.

The strategy for improving the quality of land services in the North Luwu Regency is based on the theoretical basis put forward by Osborne \& Plastrik (1997), in principle, it has not fully supported efforts to improve the quality of land services in North Luwu Regency. Various inhibiting factors in carrying out the strategy to improve the quality of land services include apparatus personnel who are not yet fully capable of carrying out service functions based on predetermined SOPs, including the lack of human resources with expertise in land affairs. Apart from that, the support for facilities and infrastructure which greatly supports the implementation of land service functions in the field is still very limited

From the explanation of the Head of the Office of the Ministry of Agrarian Affairs and BPN in North Luwu Regency, it is clear that the need for staff, especially those with expertise in land technical expertise, is a separate problem which is one of the obstacles in improving the quality of land services at the Ministry of Agrarian Affairs and BPN Office of North Luwu Regency.

Copyright ( 2020, Journal of Asian Multicultural Research for Social Sciences Study, Under the license CC BY-SA 4.0 
In addition to maintaining values, ethics, and norms in carrying out service functions to the community, the challenge in implementing a culture strategy in supporting improving the quality of land services at the Ministry of Agrarian Affairs and BPN offices in North Luwu Regency, is how to optimize existing personnel, so that can help do technical work in the field, as one of the important points in the land administration management process. This is closely related to the work ethic of the officials in carrying out land service functions to the community. Work ethic can be maximized through coaching and developing the character of employees so that they are able to show good, professional, and responsible work performance.

The various facts that the researchers found in the field, as well as the explanations of several informants related to the work culture and work ethic of the land service apparatus at the BPN Office of LuwuUtara Regency, provide a real picture that the essence of the nature of the service is almost neglected, or even unable to be realized in real terms. maximum service to citizens. The apparatus does not hesitate and is not ashamed to take action outside the rules. This means that the culture of shame for some officials is no longer a means of self-control in carrying out their duties and functions as a public service apparatus.

The various obstacles and obstacles faced in realizing the organizational culture strategy, especially mental and apparatus character development, are challenges and homework for the Office of the Ministry of Agrarian Affairs and BPN of North Luwu Regency to continue to strive to improve the quality of land services, thorough evaluation and reflection of service performance in the scope of Office of the Ministry of Agrarian Affairs and BPN of North Luwu Regency.

\section{Conclusion}

The strategy for improving the quality of land services in North Luwu Regency is based on the theoretical foundation put forward by Osborne and Plastrik, namely the core strategy, consequence strategy, customer strategy, control strategy, and culture strategy, in principle, it has not fully supported efforts to improve the quality of land services in North Luwu Regency. Various inhibiting factors in implementing the strategy to improve the quality of land services, including the capacity and capability of the apparatus personnel who are not yet fully capable of carrying out service functions based on predetermined SOPs, including the lack of human resources who have expertise in the land sector. Apart from that, the support for facilities and infrastructure which greatly supports the implementation of land service functions in the field is still very limited.

\section{References}

Alvesson, M., \& Sveningsson, S. (2015). Changing organizational culture: Cultural change work in progress. Routledge.

Denhardt, R. B., \& Denhardt, J. V. (2003). The new public service: An approach to reform. International Review of Public Administration, 8(1), 3-10.

Dwiyanto, A. (2003). Reformasi Pelayanan Publik: Apa yang harus dilakukan. Policy Brief. Pusat Studi Kependudukan dan Kebijakan UGM.

Dwiyanto, A. (2008). Reformasi Birokrasi Publik di Indonesia. Yogyakarta: Pusat Studi Kependudukan dan Kebijakan UGM.

Huberman, A. M., Miles, M., \& Saldana, J. (2014). Qualitative data analysis: A methods sourcebook. The united states of America: SAGE publications.

Hyndman, N., \& Eden, R. (2000). A study of the coordination of mission, objectives and targets in UK executive agencies. Management Accounting Research, 11(2), 175-191. 
Negara, I. S. (2020). Socio-Cultural Change of Society Against Health in the Village of Panciro, Gowa Regency. Journal La Sociale, 1(1), 19-24.

Noor, I. (2013). Desain Inovasi Pemerintahan Daerah. Universitas Brawijaya Press.

Osborne, D., \& Plastrik, P. (1997). Banishing Bureaucracy: The Five Strategies for Reinventing Government. Addison-Wesley Publishing Company, Inc., 1 Jacob Way, Reading, MA 01867.

Osborne, D., \& Plastrik, P. (2001). Trimming Bureaucracy: Five Strategies Towards Entrepreneurial Government. Jakarta: CV. Taruna Grafica.

Perry, J. L. (2007). Democracy and the new public service. The American Review of Public Administration, 37(1), 3-16.

Rudianto, Y. (2012). Implementasi Kebijakan Penyusunan dan Penetapan Standar Pelayanan Minimal Pada Dinas Kebersihan, Pertamanan, dan Pemadam Kebakaran Kabupaten Bekasi. Jurnal Administrasi Dan Kebijakan Publik, 1(2), 50-80.

Rusli, B. (2013). Kebijakan Publik Membangun Pelayanan Publik Yang Responsif. Bandung: Hakim Publishing.

Windrum, P. (2008). Innovation and entrepreneurship in public services. Innovation in public sector services: Entrepreneurship, creativity and management, 3-20. 